\title{
Sharing the Burden of Collective Security in the European Union
}

\author{
Han Dorussen, Emil J. Kirchner, \\ and James Sperling
}

\begin{abstract}
This article compares European Union (EU) burden-sharing in security governance distinguishing between assurance, prevention, protection, and compellence policies. We employ joint-product models and examine the variation in the level of publicness, the asymmetry of the distribution of costs and benefits, and aggregation technologies in each policy domain. Joint-product models predict equal burdensharing for protection and assurance because of their respective weakest-link and summation aggregation technologies with symmetric costs. Prevention is also characterized by the technology of summation, but asymmetry of costs implies uneven burden-sharing. Uneven burden-sharing is predicted for compellence because it has the largest asymmetry of costs and a best-shot aggregation technology. Evaluating burden-sharing relative to a country's ability to contribute, Kendall tau-tests examine the rank-correlation between security burden and the capacity of EU member states. These tests show that the smaller EU members disproportionately shoulder the costs of assurance and protection; wealthier EU members carry a somewhat disproportionate burden in the provision of prevention, and larger EU members in the provision of compellence. When analyzing contributions relative to expected benefits, asymmetric marginal costs can largely explain uneven burden-sharing. The main conclusion is that the aggregated burden of collective security governance in the EU is shared quite evenly.
\end{abstract}

The creation and maintenance of peace and security in Europe has been a persistent and fundamental ambition of the European project. The European Union (EU) has only recently acquired a tangible security role. The precise limitations and opportunities for the EU to emerge as a security actor after 1989 remain subject to extensive debate. ${ }^{1}$ This research note makes two contributions to the debate. First, the multifaceted nature of security reveals considerable variation in the produc-

We would like to thank Max Rasch and Susan Sydenham. We would like to acknowledge financial assistance by the FP-6 Garnet and British Academy (SG-46165) for the research of this article.

1. See Hill 1993; Sperling and Kirchner 1997; Smith 2004; and Jones 2007. 
tion of security goods; accordingly, the joint-product analysis ${ }^{2}$ provides an appropriate framework to study EU security governance as a collective-action problem. Second, we find the smaller EU member states are not free-riding in the provision of collective security policies, contrary to one of the central hypotheses in the public-choice literature, ${ }^{3}$ and demonstrate that in fact EU member states equitably share the costs attending the various dimensions of security governance.

EU prerogatives have always relied on the delegation of member-state authority, but the delegation of authority in security matters is generally incomplete, uneven in application, and in many instances nonbinding. Member-state contributions to EU security governance consequently vary, limit EU effectiveness as a security actor, and beg an important question: do the member states share equitably the burden of security governance? Joint-product models hold that burdensharing depends on the method whereby differentiated security tasks are produced (that is, their aggregation technology or how individual contributions combine to provide security) as well as variation in costs and benefits.

In their application of public-goods models, Olson and Zeckhauser find evidence supporting the exploitation hypothesis that alliances, such as the North Atlantic Treaty Organization (NATO), are likely to provide a suboptimal level of defense with burdens mainly imposed on large allies with disproportionate benefits and relatively low marginal costs. ${ }^{4}$ Koenig-Archibugi and Webber and colleagues claim that the barriers to the effectiveness of EU security governance reflect variations in member-state interests and identity as well as complications engendered by enlargement, respectively. ${ }^{5}$ Their findings would be unexpected if the Common Foreign Security Policy (CFSP) or European Security and Defense Policy (ESDP) solely entailed collective-action problems, because the exploitation hypothesis would predict that the large states, once committed to CFSP or ESDP, would support strengthening institutional linkages to minimize small-state opportunities for free-riding. A more general conceptualization of the production of security governance therefore seems appropriate.

Security governance involves outputs with varying degrees of publicness and distinctive production technologies. The theory of impure public goods, ${ }^{6}$ or jointproduct models, highlights the importance of private defense benefits. Disproportional burden-sharing has been related to specific security tasks; for example, NATO

2. Sandler 1977 provides the original joint-product analysis; see also Sandler 1992; and Hirshleifer 1983.

3. Olson and Zeckhauser 1966.

4. Following Olson 1965 and Olson and Zeckhauser 1966, the debate on burden-sharing or "fairshare" has mainly focused on NATO comparing the EU members with the United States. Focusing on security burden-sharing within the EU, Chalmers (2000, 80-114) argues for a small-state bias in the $\mathrm{EU}$, but otherwise largely discounts the continued relevance of "public goods" theories to explain burden-sharing.

5. See Koenig-Archibugi 2004, 159; and Webber et al. 2004, 17.

6. See Buchanan 1965; Sandler 1977 and 1992; Sandler and Hartley 2001; and Sandler and Tschirhart 1980. 
security tasks now vary from strategic deterrence to large-scale military intervention, and peacekeeping with a UN mandate. ${ }^{7}$ EU prerogatives and policy instruments also vary across security governance policies - the allocation of security tasks between the three pillars ${ }^{8}$ that formally defines the relative authority of EU institutions. Supranational principles govern those security tasks delegated to Pillar I, where the Commission possesses a central policy-setting role and the Council takes decisions by qualified majority. Intergovernmentalism and unanimity voting in the Council, qualified by the principle of constructive abstention, apply to Pillar II; this pillar encompasses human rights, democratization, and traditional security tasks. Police and judicial cooperation are reserved for Pillar III, justice and home affairs (JHA). Those policies allocated to Pillar III remain largely subject to member-state sovereign prerogatives; the EU can only act on the basis of unanimity, and the decisions are legally nonbinding.

Previously, Kirchner and Sperling ${ }^{9}$ have argued that security governance, which requires the EU (and its member states) to perform two functions-institutionbuilding and conflict resolution - and employ two sets of instruments - the persuasive (economic, political, and diplomatic) and the coercive (military intervention and internal policing)_-generates four categories of governance policies: assurance, prevention, protection, and compellence (see Table 1). Assurance, prevention, and compellence concern the EU's external environment. Conflict prevention captures efforts to build or sustain institutions mitigating anarchy and contributing to order. Assurance targets postconflict reconstruction and attending confidencebuilding measures. Compellence encompasses military interventions, primarily peace-enforcement and peace-keeping. Protection addresses the requirements of internal security. The four tasks are often pursued concurrently and often combine economic and military instruments. However, an elective affinity exits between policy instruments and specific governance challenges. Prevention is largely conducted within the legal framework of Pillar I, assurance policies involve both Pillars I and II, compellence is positioned in Pillar II, while protection is primarily situated in Pillar III.

In the next sections, we elaborate on the specific production technologies of EU governance tasks and discuss variations in their levels of publicness. In the subsequent empirical section, we explore how EU member states have dealt with the collective-action problems attending security governance. Partially contradicting expectations based on public-goods models, the burdens of collective security governance are shared more or less equitably, although the larger, wealthier EU members overcontribute to compellence and prevention activities, while the smaller

7. See Khanna and Sandler 1996 and 1997; Sandler and Forbes 1980; Sandler and Murdoch 2000; Arce and Sandler 2002; Shizumu and Sandler 2002; and Lindstrom 2005.

8. The Lisbon Treaty dismantles the pillar system. If the treaty is ratified in 2009, it would not change the substance of the argument: Pillar I and Pillars II and III would be governed by the Community and the intergovernmental methods, respectively.

9. Kirchner and Sperling 2007. 
members overcontribute to the provision of assurance and protection. Asymmetrical marginal costs and benefits largely explain this uneven pattern of burden-sharing.

TABLE 1. Typology of security governance policies

\begin{tabular}{lll}
\hline & \multicolumn{2}{c}{ Instruments } \\
\cline { 2 - 3 } Functions & Persuasive & Coercive \\
\hline Institution-building & Prevention & Protection \\
Conflict resolution & Assurance & Compellence \\
\hline
\end{tabular}

\section{EU Security Governance: Assurance, Prevention, Compellence, and Protection}

The intensity of the collective-action problem vexing each category of security governance depends on levels of publicness (that is, excludability and rivalry), asymmetry of (marginal) costs and benefits, and the governing aggregation technology; namely, summation, best-shot, and weakest-link functions. In case of a summation technology, all individual contributions add equally to the supply of the public good. For best-shot technologies, the largest individualized contribution matters most, and the smallest contributions are decisive in case of weakestlink technologies. ${ }^{10}$ The general expectation is that burdens will be shared less evenly if on balance the goods are less "public" and asymmetries more relevant in a particular category of security governance. ${ }^{11}$

\section{Assurance}

With the end of the Cold War, the EU had to deal with the postconflict consequences of political instability at its borders. Initially, assurance policies sought to address the immediate dislocations attending the political transition in Central and Eastern Europe and to alleviate postconflict political instability in the Balkans and the Mediterranean basin, including the provision of humanitarian assistance. Since the 2000 Nice summit, which finalized the eastern enlargement, assurance policies

10. Sandler 1992 provides a comprehensive introduction into various aggregation technologies.

11. Sandler 1977, 444-48, distinguishes between protective and deterrent defense goods. Arce and Sandler $(2002,28)$ also relate classes of public goods to optimality and proposed institutional arrangements. 
have mainly engaged fragile postconflict regimes along the EU perimeter toward fostering regional political stability. Milieu stability is a public good: EU members (or any other regional state) neither compete in its consumption nor can be excluded from doing so. The EU member states are equally interested in assurance. Open internal borders diffuse the negative consequences of political instability throughout the EU, even though states with external borders on the EU's southern and eastern borders may fear regional instability more. The distribution of costs and benefits is relatively symmetric and summation best describes the aggregation technology, since assurance mainly relies on the combined efforts of the EU. Consequently, we expect equitable burden-sharing in this policy domain.

\section{Prevention}

Prevention seeks political stability via the expansion of governing capacity, facilitating economic (re)development, and the containment of political strife between opposing societal groups. ${ }^{12}$ Prevention represents long-term or "second-stage" security goals and targets failing states globally. Global political stability is a pure public good: states can neither be excluded from its benefits nor are they rivals in its consumption. Prevention also provides significant private benefits: it allows national governments to demonstrate global importance and enhances their leverage over target countries. The private benefits are diluted when prevention is perceived principally as a collective effort or executed under the EU aegis. Threats posed by failed states affect all member states evenly: refugees arrive in Europe at multiple points of entry ${ }^{13}$ and negative economic externalities diffuse quickly across Europe. EU members differ, however, in their ability to intervene. Colonial ties are relevant; for example, the United Kingdom (UK) can use the Commonwealth, and France can use the less-institutionalized "France and Africa" summits to influence destabilizing developments. The major members, especially the formal colonial powers, are most important for diplomatic engagement. Prevention however relies mainly on funds available for long-term foreign aid where all contributions are source neutral. The production of prevention thus combines best-shot and summation technologies, the latter more tellingly.

Prevention presents a collective-action problem for the EU. Individual countries are unlikely to feel sufficiently threatened by the risks of state failure in distant places to fund these policies fully on their own. At the same time, the private benefits attending these policies and the differentials in (marginal) costs vary across member states. Since some members have an incentive to provide prevention policies outside the EU, we expect, on balance, free-riding to be a more serious problem as compared to assurance.

12. Kirchner and Sperling 2007, 28-29.

13. Thielemann and Dewan 2006 demonstrate that smaller EU countries carry a disproportionate burden in providing refugee protection. 


\section{Compellence}

Compellence relies on the use of force or coercion. The Peterberg tasks, which define the EU compellence portfolio, reflect the continuing relevance of coercion to alleviate security threats. The principle of solidarity underpins any collective EU military response. Since a threat against any EU member risks escalation and Europe's political destabilization, the ability to address it jointly has public-goods aspects. Yet, the line between threats against a core national interest as opposed to a core EU interest is ambiguous and contestable. Compellence thus allows for exclusion. Further, whenever member states differ in their risk assessment, the distribution of benefits will be asymmetric. Resource constraints further complicate joint action: the military participation of various EU members in Iraq and Afghanistan has not only stretched national military resources, but also hampers effective EU action elsewhere (for example, in Darfur).

Even more importantly, EU members vary greatly in their ability to contribute to compellence. NATO members are better prepared to execute a joint response, since their military forces are interoperable and have participated in large-scale joint exercises. In contrast, the traditionally neutral EU members are oriented toward territorial defense and consequently ill-equipped to participate in multilateral military operations. France and the UK are the only members with an independent capability to project military force; their involvement is a necessary condition for EU action and determines operational effectiveness. Comparing the categories of security governance, compellence is the closest example of a best-shot production technology. Hirshleifer argues that the best-shot production technology enhances the risk of exploitation. ${ }^{14}$ Although the EU has a clearly stated interest in emphasizing common security interests, we expect burden-sharing to be quite uneven and the EU to rely on a fixed intergovernmental coalition of its largest members to render coercion effective.

\section{Protection}

The Amsterdam Treaty established the goal of a European area of freedom, security, and justice as the core objective of EU protection policies. Internal security requires member states to harmonize their institutional and legal infrastructures and covers a wide spectrum of issues, including narcotics trafficking, terrorism, organized crime, epidemiological surveillance, the policing of external borders,

14. Hirshleifer 1983, 380-83. The precise relation between group size and free-riding depends on the characteristics of the members being added (Sandler 1992, 52). If EU enlargement had meant including countries with a strong interest in compellence as well as matching capabilities, it would have eased any free-riding problems. 
and infrastructure security. It falls under the aegis of Pillar III, where progress on EU cooperation has been slow. ${ }^{15}$

Harmonization of legal infrastructure, sharing of information, and policy coordination avoids the negative externalities of lax or asymmetrical enforcement of national law. Protection is clearly an impure public good. Exclusion is feasible: countries may decide to stop sharing information or to (temporarily) limit the free access of people or goods from specific countries. Protection also suffers from force-thinning, since resources are often targeted toward particular areas, and stricter rules and enforcement in a particular region may displace criminal activities across borders. ${ }^{16}$ Finally, governments can derive private benefits by taking credit for locally reduced crime and increased security. The asymmetry of threat perception depends on the type of crime under consideration. Crime varies considerably across Europe, but concerns about cross-border criminal activities are spread more evenly. The latter are the main target of Pillar III policies. Larger and richer countries have lower marginal costs of contributing to collective protection policies (for example, resources for police and judiciary, collecting and sharing information, and aligning legal and institutional frameworks).

The weakest-link aggregation technology applies to protection with respect to its provision as a public good. Member states with the most lenient penal codes and the least willingness to share information limit the ability to achieve the common goal of combating organized crime, terrorism, or pandemics, natural or otherwise. The removal of internal barriers allows the (relative) failure of a weakest-link provider to spread across Europe. Organized crime and terrorist cells seek out safe havens, but their operations affect citizens across Europe. The privategoods aspects, as well as weakest-link aggregation technology, actually decrease the collective-action problems for protection policies. EU members may contribute voluntarily and approximate the optimal joint supply of protection. In so doing, states attain the private gains from protection and avoid weakest-link externalities. Variation in the marginal costs would explain redistribution of resources from richer to the poorer EU members, where the credible threat of exclusion should discourage exploitation.

\section{Summary}

The central hypothesis from joint-product models is that burden-sharing in EU security governance varies across security policies. Equal burden-sharing is expected for protection and assurance because of their respective weakest-link and summation aggregation technologies conjoined to symmetric costs. In contrast, large countries are expected to shoulder the costs of prevention and compellence. The technology of summation also describes prevention, but asymmetry of costs is expected to lead

15. Hix 1999, 307-30.

16. Sandler and Hartley 2001, 876. 
to uneven burden-sharing. Uneven burden-sharing is predicted for compellence because of its best-shot aggregation technology, where a committed effort of the major players is often decisive. Moreover, issues lending themselves to coercion often involve asymmetric threats and the marginal costs of a military operation are spread unevenly as well.

\section{Data and Research Design}

To assess the central hypothesis that the larger EU states carry a disproportionately greater burden for compellence and prevention governance policies, while EU states share the burden for assurance and protection polices more equitably, we need to make three preliminary determinations: (1) the activities to include in the calculation of burden-sharing; (2) the allocation of those activities to the various dimension of security governance; and (3) the appropriate benchmarks for defining equitable burden-sharing. Regarding the first point, we have chosen to exclude activities falling under the Community budget since the gross national income (GNI) key largely determines national contributions, and burdens are by definition shared equitably.

The defining aspect of assurance is the emphasis on persuasion to sustain order and create democratic institutions in a postconflict environment. Assurance encompasses postconflict missions and efforts to improve domestic governance, including border control, policing, and criminal justice. Most missions have taken place in the near abroad, but there have been some in Africa and one in Southeastern Asia. For the Balkans, these policies are linked with the Stability and Association Process (SAP). ESDP missions focusing on the civilian aspects of humanitarian and crisis management tasks are categorized as assurance missions. Compellence focuses on coercive measures to resolve conflict. Apart from economic and political sanctions, ESDP military missions and NATO/U.S.-led missions comprise this category of security governance. ${ }^{17}$

Missions have common costs and operational costs. The allocation of common costs is in accordance with the GNI-key unless the Council unanimously decides otherwise, and members opting out of a particular mission generally do not share in the common costs. The Community budget allocated a total of $€ 212$ million to ESDP missions in the period 2003-May 2005. Common costs cover the overhead costs during the preparatory and active phases of an operation, including force headquarters, specific transportation costs, medical costs, and local staff. Participating states cover operational costs according to the principle of "costs lie where they fall." These costs include the budget for troops and civilian personnel, and the deployment of equipment to areas of operation. Operational costs tend to be

17. See $\langle$ http://privatewww.essex.ac.uk/ hdorus $\rangle$ for a listing EU operations and actions according to the category of security policy. Accessed 2 July 2009. 
greater than common costs. ${ }^{18}$ We rely on the deployment of military and civilian personnel to ESDP operations as a proxy for the distribution of operational costs. Country contributions are measured in approximate person-years, accounting for some missions starting or ending midyear.

Prevention covers a wide range of humanitarian and development assistance programs as well as a number of EU partnerships with countries in particular geographical regions, which tend to fall under the Community budget. The partnership with African, Caribbean, and Pacific nations, as well as Overseas Countries and Territories (ACP-OCT), is special because it is funded by the European Development Fund (EDF) and is kept separate from the Community budget. The EDF contributions are voluntary and the programs are negotiated multilaterally with the recipients.

Policies of protection do not yield easily usable and comparable data. There is data on European cooperation on law enforcement (Europol) and judicial matters (Eurojust). Europol is largely funded by contributions from the member states according to the GNI-key, while Eurojust is funded directly by the European Commission. To assess burden-sharing for protection policies, we use the Eurojust case load.

It is obviously important to reflect on the baseline to assess the "fairness" of contributions. The principle that has developed in the EU common budget is an equitable contribution relative to GNI. It is reasonable to expect that ability to pay also matters for burden-sharing outside the Community budget. The Kendall tautest is an appropriate nonparametric statistical test to evaluate burden-sharing relative to the ability to contribute. Kendall tests rely on a comparison of rankings and assume ordinal-level data. Since it does not require any assumption about normality of the error terms, it is less affected by the small number of observations. The null hypothesis is that there is no correlation between the ranking on resources available and the ranking of share of resources committed to collective security policies. The Kendall tau-statistic ranges from -1 to +1 . If tau $>0$, states with more resources contribute a larger share of their resources, and if tau $<0$, they contribute a smaller share. A rejection of the null hypothesis therefore suggests a positive (negative) relation indicating exploitation of the strong (weak) by the weak (strong). Contributions to prevention policies are in monetary terms, making it appropriate to measure share of resources relative to gross domestic product (GDP). The Kendall tau-test compares the ranking of member contributions relative to their economic size (CONTRIBUTION $i / \mathrm{GDP}_{i}$ ) with their purchasing power parity GDPranking. Instead of capacity, it is also appropriate to use wealth (measured as GDP per capita) as a baseline. ${ }^{19}$ Contributions to assurance and compellence mission are in person-year and measured as share of population. Contributions to protection policies are in terms of information provided in response to requests and infor-

18. Lindstrom 2005, 36.

19. See Shizumu and Sandler 2002, 665-66. 
mation meetings attended. Sandler and Hartley ${ }^{20}$ refer to the Kendall tau-test as a test of within-ally burden-sharing and note that it only partly controls for asymmetric costs and benefits.

An alternative conception of fairness derives from the distribution of benefits: contributions should be relative to the enjoyment of the collectively produced good. The among-ally burdens measure relates the share of a particular EU member to total EU spending (CONTRIBUTION ${ }_{i} /$ CONTRIBUTIONS $_{E U}$ ) to its share of derived (expected) benefits from the common policy (BENEFITS ${ }_{i} /$ BENEFITS $_{E U}$ ). Sandler and Forbes measure the benefits from NATO defense as an index of an ally's industrial base, its population, and exposed borders. ${ }^{21}$ Following a similar approach, we measure assurance benefits based on industrial base (GNI), social protection, Eastern and Mediterranean borders, and number of asylum-seekers. In the case of prevention policies, GDP measures expected benefits. ${ }^{22}$ Benefits from compellence are based on industrial base (the GNI-key). For protection policies, benefits are measured by all requests made to Eurojust, EU homicides, and EU violent deaths. Regression analyses evaluate among-ally fairness where the dependent variable is operationalized as:

$$
Y=\ln \left[\left(\frac{\text { Contributions }_{i}}{\sum_{i \in E U} \text { Contributions }_{i \in E U} \text { Benefits }_{i}}\right)+1\right]
$$

The log-transformation corrects for the fact that, by construction, countries accruing a small share of the benefits are more liable to overcontribute dramatically. The expected country share of benefits is the central independent variable. A positive coefficient indicates that countries with larger shares of benefits contribute disproportionately more to the collective provision, while a negative coefficient indicates that they contribute disproportionately less. ${ }^{23}$

We include controls for EU members with less than a million citizens (Luxemburg, Cyprus, and Malta), for the ten accession states-Poland, the Czech Republic, Slovakia, Hungary, Slovenia, Latvia, Lithuania, Estonia, Malta, and (Greek) Cyprus, and when appropriate for non-NATO members and bilateral foreign aid. In the case of assurance policies, we compare missions along the European perim-

20. Sandler and Hartley 2001, 883.

21. Sandler and Forbes 1980.

22. We use data two years prior to the start of a particular EDF round with the exception of the final round, for which the latest data available are 2004.

23. Sandler and Forbes 1980; and Sandler and Hartley 2001 report the results from Wilcoxon tests. The Wilcoxon tests rely on a ranking of differences. Similarity of two-distribution is assessed by any difference in the sum of positive and negative rankings. When comparing two variables that are both measured as shares (by construction with equal means), the Wilcoxon test thus becomes extremely conservative. 
eter with those further afield. For compellence missions, the relevant comparison is between EU-led and NATO/U.S.-led missions.

\section{EU Security Governance and Burden-Sharing}

Since the data for the four security issues are not fully comparable, we first assess burden-sharing for each category separately. The comparison across categories is left for the discussion.

\section{Prevention}

The budgeting of prevention policies is partly under the remit of the Commission, but a significant part of the EU overseas development aid is funded through the EDF. Over time, the EDF budget has expanded greatly, but the share of the ten accession states was limited in the tenth (and most recent) EDF round.

Table 2 compares the ranking of the EU member-state EDF budgets relative to GDP, with their rankings in size (total GDP) and wealth (GDP per capita). The GDP data are lagged for two years prior to the finalization of each EDF round to account for period of negotiation prior to agreement. The first row shows generally no significant relation between ranking in the EDF budget and country size for each of the ten EDF rounds completed so far. The only exception is the tenth EDF round, but the positive rank-correlation is not significant for the EU15 (Austria, Belgium, Denmark, Finland, France, Germany, Greece, Ireland, Italy, Luxembourg, the Netherlands, Portugal, Spain, Sweden, and the UK) and accession states analyzed separately. The positive rank-correlation thus mainly reflects the disproportionately smaller contributions of the accession states. Interestingly, we can reject the null hypothesis of even burden-sharing relative to wealth (GDP per capita) for the more recent EDF rounds. There is a significant positive rank-correlation between EDF contributions and wealth. The tau statistics show that richer countries spend a larger proportion of their GDP on prevention, and the relationship becomes significant after the "southward" enlargement of the EU. The inclusion of the relatively poor Mediterranean states made the EDF more dependent on the richer north. Subsequent enlargements have not affected the overall picture.

A comparison of the among-ally burden shares gives a somewhat different picture. Table 3 gives the results of regressing EDF contribution relative to share of expected benefits (measured as country's share of total EU GDP) on size and wealth, and, where appropriate, using EDF round, accession states, bilateral foreign aid, and the former colonial powers as further controls. The first two models include information from all ten EDF rounds, while the latter four models examine the possible impact of the eastward enlargements in the final EDF. The negative and significant coefficient for size shows that the larger EU members contribute less than would be expected based on derived benefits. Countries that spend more on 


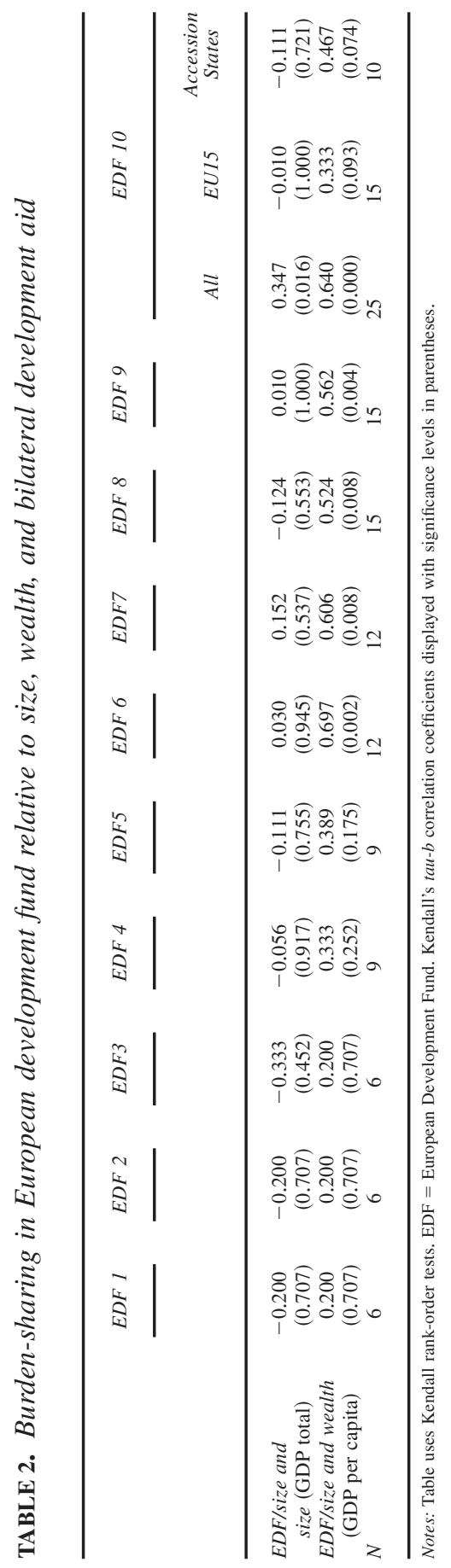


bilateral foreign aid also tend to contribute disproportionately to the EDF budgets ${ }^{24}$ while the accession states fail to contribute proportionally. Depending on model specification, the former colonial powers contribute disproportionately. Even controlling for foreign aid, richer countries contribute disproportionately to the EDF budget, while larger (that is, more populous) countries generally contribute less.

TABLE 3. Determinants of EDF-share relative to country size for wealth, population, and aid shares

EDF/size (ln)

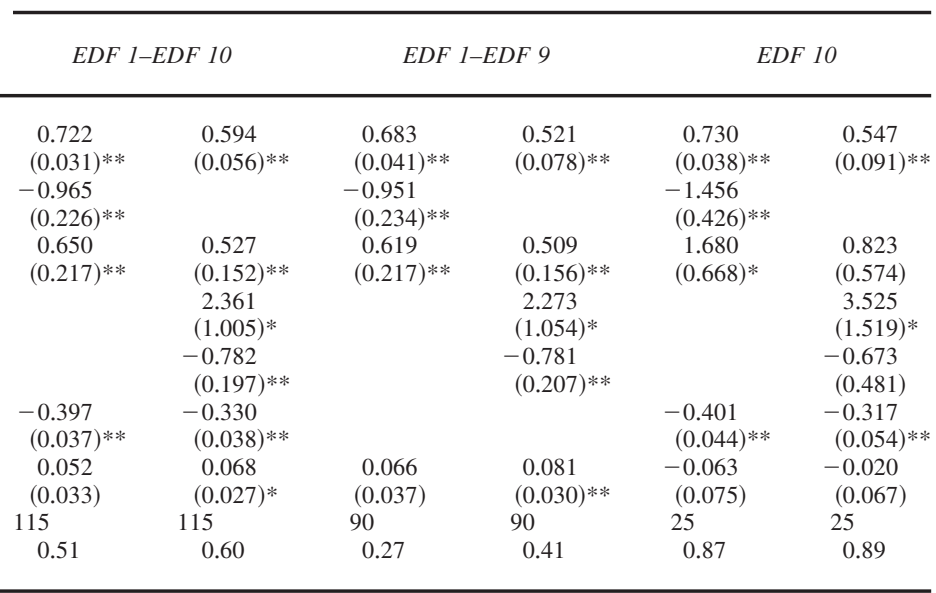

Notes: Table uses ordinary least squares (OLS) regression. Foreign aid: bilateral aid as share of EC/EU total (OECD). Colonial powers: Belgium, France, the Netherlands, Portugal, Spain, and the United Kingdom. EDF = European Development Fund. Models include dummy-variables for each EDF-round, not presented. Robust standard errors in parentheses. * significant at 5\%; ** significant at $1 \%$.

The results for prevention policies thus reveal more even burden-sharing than predicted by the joint-product model. The ability to pay and lower marginal costs of allocating funds to foreign aid are strongly related to contributions to EDF programs. The Kendall tau results, however, suggest that total GDP (as an indication of ability to contribute) only has a limited impact. The regression analyses even suggest that larger countries fail to contribute relative to their share of expected benefits.

\section{Compellence}

There is clear variation in the involvement of EU members in military operations. Most notably, Denmark does not contribute to EU-led operations, while it is active

24. Domestic political institutions may well explain lower marginal costs of contributing to foreign aid (Noël and Thérien 1995), but significantly, even controlling for bilateral official development assistance (ODA), EU institutions appear ineffective in overcoming any such bias. 
in NATO/U.S.-led operations. The UK and the Baltic states are much more active in NATO/U.S.-led operations, while France and Spain focus predominantly on EU-led missions. With the exception of Sweden, the EU-neutrals-Austria, Finland, and Ireland-also contribute predominantly to EU missions. The accession states generally appear to contribute generously to compellence missions, particularly to NATO/U.S.-led missions.

Table 4 compares the ranking of troops committed to EU/NATO-led operations (relative to population) with the country-size ranking. Troop commitment appears to increase with size, but the finding is not robust when analyzing the EU15 and accession states separately. Similarly, there is no robust relation between troop commitment and wealth. The positive correlation for all missions and NATO/U.S. missions does not hold up when analyzing the EU15 and accession states separately, and thus would seem to reflect mainly the higher willingness of the newer NATO members to contribute to NATO missions.

TABLE 4. Burden-sharing of deployment for military coercive missions (MCM) relative to population, wealth, and size of the economy

\begin{tabular}{lccc}
\hline & $\begin{array}{c}\text { EU member } \\
\text { states }\end{array}$ & EU15 & $\begin{array}{c}\text { Accession } \\
\text { states }\end{array}$ \\
\hline MCM/population and size & & & \\
All missions & 0.467 & 0.143 & 0.378 \\
& $(0.001)$ & $(0.488)$ & $(0.152)$ \\
EU-led & 0.297 & 0.029 & 0.378 \\
& $(0.040)^{1}$ & $(0.921)$ & $(0.152)$ \\
NATO/U.S.-led & 0.451 & 0.105 & 0.494 \\
& $(0.002)$ & $(0.621)$ & $(0.059)^{1}$ \\
MCM/population and wealth & & & \\
All missions & 0.360 & 0.029 & -0.111 \\
& $(0.013)$ & $(0.921)$ & $(0.721)$ \\
EU-led & 0.204 & -0.162 & -0.022 \\
& $(0.161)^{2}$ & $(0.429)$ & $(1.00)$ \\
NATO/U.S.-led & 0.304 & 0.029 & -0.267 \\
& $(0.036)$ & $(0.921)$ & $(0.323)$ \\
$N$ & 25 & 15 & 10 \\
\hline
\end{tabular}

Notes: Table uses Kendall rank-order tests. Kendall's tau-b correlation coefficients displayed with significance levels in parentheses.

${ }^{1}$ No longer significant (at .1) when excluding small states (Cyprus, Luxemburg, Malta).

${ }^{2}$ Becomes significant $(<.1)$ when excluding small states.

The regression analyses (Table 5) suggests that lower marginal costs best explain disproportional contributions to coercive missions. Contrary to first impressions, the accession states no longer significantly overcontribute to compellence. Simi- 
larly, there is no significant correlation between GNI and contribution share. As to be expected, NATO members are significantly more likely to carry a larger share of the NATO/U.S.-led military missions, owing in part to the lower marginal operational costs of contributing troops attending the integrated military command and in part to the higher marginal political costs of not contributing to a NATO mission. To a large extent, the asymmetric costs of providing troops thus account for uneven burden-sharing.

TABLE 5. Determinants of deployment to military coercion missions $(M C M)$ relative to gross national income (GNI)

\begin{tabular}{lccc}
\hline & & MCM/GNI (ln) & \\
& $M C M / G N I($ ln $)$ & $\begin{array}{c}\text { MCM/GNI (ln) } \\
\text { EU missions }\end{array}$ & NATO/U.S. missions \\
\hline Constant & 0.915 & 0.896 & 0.913 \\
& $(0.170)^{* *}$ & $(0.244) * *$ & $(0.170)^{* *}$ \\
GNI (share) & -1.552 & -1.444 & -1.543 \\
& $(1.143)$ & $(1.588)$ & $(1.153)$ \\
Accession states & 0.355 & 0.076 & 0.355 \\
Non-NATO members ${ }^{2}$ & $(0.205)$ & $(0.321)$ & $(0.204)$ \\
& -0.679 & -0.364 & 0.692 \\
$N$ & $(0.234)^{* *}$ & $(0.291)$ & $(0.231) * *$ \\
$R^{2}$ & 25 & $24^{1}$ & 25 \\
& 0.56 & 0.09 & 0.57 \\
\hline
\end{tabular}

Notes: Table uses ordinary least squares (OLS) regression. Robust standard errors in parentheses.

* significant at $5 \%$;* significant at $1 \%$.

${ }^{1}$ Excludes Denmark.

${ }^{2}$ Austria, Cyprus, Finland, Ireland, Malta, and Sweden.

\section{Assurance}

In absolute terms, deployment of personnel to civilian crisis management remains modest. Table 6 compares the rankings of deployment (by population) and size, and Kendall's tau uncovers a significant negative correlation. Contrary to the exploitation hypothesis, larger countries contribute relatively less to civil crisis management. The negative correlation holds for the original EU members as well as the accession states, even when excluding the smallest EU members. The negative rank-correlation applies particularly to missions along the European perimeter, while it only applies to the EU15 members for missions in Africa and Asia. In contrast, the rank-correlation between deployment and wealth is nearly always insignificant. Therefore, we cannot reject the null hypothesis that rich and poor countries contribute evenly to civil crisis management. The only exception is that the richer 
EU members contribute more to civil crisis management in Africa and Asia, but the finding is not robust when evaluating EU15 and accession states separately.

TABLE 6. Burden-sharing of deployment for civil crisis management $(C C M)$ relative to population compared to wealth and size of the economy

\begin{tabular}{lccc}
\hline & $\begin{array}{c}\text { EU member states } \\
\text { All }\end{array}$ & $\begin{array}{c}\text { EU15 } \\
\text { All }\end{array}$ & $\begin{array}{c}\text { Accession states } \\
\text { All }\end{array}$ \\
& & & \\
\hline CCM/population and size & -0.633 & -0.581 & -0.911 \\
All missions & $(0.000)$ & $(0.000)$ & $(0.000)$ \\
Europe and Middle East & -0.673 & -0.581 & -0.911 \\
& $(0.000)$ & $(0.003)$ & $(0.000)$ \\
Africa and Asia & 0.127 & -0.410 & 0.109 \\
& $(0.397)$ & $(0.038)$ & $(0.760)$ \\
CCM/population and wealth & & & \\
All missions & 0.047 & 0.295 & 0.378 \\
Europe and Middle East & $(0.761)$ & $(0.138)$ & $(0.152)$ \\
& -0.007 & 0.257 & 0.378 \\
Africa and Asia & $(0.981)$ & $(0.198)$ & $(0.152)$ \\
& 0.496 & 0.276 & 0.054 \\
$N$ & $(0.001)$ & $(0.166)$ & $(0.919)$ \\
& 25 & 15 & 10 \\
\hline
\end{tabular}

Notes: Table uses Kendall rank-order tests. Kendall's tau-b correlation coefficients displayed with significance levels in parentheses.

Table 7 presents the results of regressing deployment relative to benefits as a function of each country's share of benefits, controlling for the accession states. Analysis of among-ally burdens shows that states deriving a larger share of the benefits significantly undercontribute to civil crisis management missions. The coefficients for the index of benefits are negative and significant for all types of missions. The last three models show that GNI-share and share of the EU frontier are both significant: larger and more exposed countries are failing to contribute proportionally. ${ }^{25}$ Accession states appear less willing to contribute to missions further afield. To summarize, even accounting for asymmetries in marginal costs and benefits, the smaller EU members appear to contribute more than their "fair" share to assurance missions.

25. Due to their high colinearity with GNI-share and border-length, it is impossible to include the other elements of the Index (social protection and asylum-seekers) separately in the model. 
TABLE 7. Determinants of deployment to civil crisis management (CCM) relative to expected benefits

\begin{tabular}{|c|c|c|c|c|c|c|}
\hline & \multicolumn{3}{|c|}{$C C M /$ index $(\ln )$} & \multicolumn{3}{|c|}{$C C M /$ index $(\ln )$} \\
\hline & All & $\begin{array}{c}\text { Europel } \\
\text { Middle East }\end{array}$ & $\begin{array}{c}\text { Africal } \\
\text { Asia }\end{array}$ & All & $\begin{array}{c}\text { Europel } \\
\text { Middle East }\end{array}$ & $\begin{array}{c}\text { Africal } \\
\text { Asia }\end{array}$ \\
\hline Constant & $\begin{array}{l}1.200 \\
(0.155)^{* *}\end{array}$ & $\begin{array}{l}1.103 \\
(0.120) * *\end{array}$ & $\begin{array}{l}1.343 \\
(0.237)^{* *}\end{array}$ & $\begin{array}{l}1.162 \\
(0.160) * *\end{array}$ & $\begin{array}{l}1.060 \\
(0.122) * *\end{array}$ & $\begin{array}{l}1.336 \\
(0.245) * *\end{array}$ \\
\hline Index (share) & $\begin{array}{l}-5.733 \\
(1.561)^{* *}\end{array}$ & $\begin{array}{l}-5.007 \\
(1.296) * *\end{array}$ & $\begin{array}{c}-6.754 \\
(2.410)^{*}\end{array}$ & & & \\
\hline GNI (share) & & & & $\begin{array}{l}-2.889 \\
(0.914)^{* *}\end{array}$ & $\begin{array}{l}-2.467 \\
(0.790) * *\end{array}$ & $\begin{array}{l}-3.669 \\
(1.483) *\end{array}$ \\
\hline Border (share) & & & & $\begin{array}{l}-2.040 \\
(0.375)^{* *}\end{array}$ & $\begin{array}{l}-1.677 \\
(0.327)^{* *}\end{array}$ & $\begin{array}{c}-2.767 \\
(0.554) * *\end{array}$ \\
\hline Accession states & $\begin{array}{r}-0.039 \\
(0.232)\end{array}$ & $\begin{array}{c}0.219 \\
(0.236)\end{array}$ & $\begin{array}{l}-1.129 \\
(0.237)^{* *}\end{array}$ & $\begin{array}{c}-0.025 \\
(0.252)\end{array}$ & $\begin{array}{c}0.240 \\
(0.256)\end{array}$ & $\begin{array}{l}-1.143 \\
(0.255) * *\end{array}$ \\
\hline$N$ & 25 & 25 & 25 & 25 & 25 & 25 \\
\hline$R^{2}$ & 0.25 & 0.30 & 0.55 & 0.26 & 0.29 & 0.61 \\
\hline
\end{tabular}

Notes: Table uses ordinary least squares (OLS) regression. GNI = gross national income. Index of GNI-share, length of Eastern and Mediterranean borders, number of asylum seekers, and social protection as share of EU total. Robust standard errors in parentheses. * significant at $5 \%$; ** significant at $1 \%$.

\section{Protection}

Information for protection policies is much less complete as we only rely on Eurojust data. The number of coordination meetings attended and the number of information requests are used as an indicator of contributions. Table 8 compares the ranking of contributions to Eurojust (relative to the size of a country's police force) with the ranking of total GDP. The main finding is that smaller countries overcontribute to Eurojust. This finding is stronger for the period 2004-2006 and holds for both the original EU members and the accession states. The findings for contributions to Eurojust relative to wealth are less clear. The richer EU15 countries appear to overcontribute. However, for the EU as a whole and the accession states, the null hypothesis for even burden-sharing cannot be rejected.

Table 9 examines among-ally burden-sharing. The countries' share in the number of coordination meetings and received information requests measures the among-ally distribution of contributions. Benefits reflect the amount of requests made to Eurojust and a country's serious crime. The unexpected finding, based on joint-product models, is that contributions to joint protection appear to be inversely related to derived benefits, even controlling for accession states that are less likely to overcontribute.

\section{Conclusion}

Burden-sharing is a relevant issue in EU security governance that is likely to grow in importance as the EU seeks an autonomous ability to act effectively across the 
TABLE 8. Burden-sharing of European justice provision relative to police force

\begin{tabular}{lccc}
\hline & EU member states & EU15 & Accession states \\
\hline $\begin{array}{l}\text { European justice } \\
\text { provision/police and size }\end{array}$ & & & \\
$\quad$ 2001-2003 & & -0.333 & \\
& & $(0.093)$ & \\
$2004-2006$ & -0.467 & -0.410 & -0.956 \\
& $(0.001)$ & $(0.038)$ & $(0.000)$ \\
European justice & & & \\
provision/police and wealth & & & \\
2001-2003 & & 0.429 & \\
$2004-2006$ & 0.207 & $0.029)$ & 0.422 \\
& $(0.154)$ & $(0.038)$ & $(0.107)$ \\
$N$ & 25 & 15 & 10 \\
\hline
\end{tabular}

Notes: Table uses Kendall rank-order tests. Kendall's tau-b correlation coefficients displayed with significance levels in parentheses.

TABLE 9. Determinants of contributions to European justice provision relative to benefits index

\begin{tabular}{|c|c|c|}
\hline & $\begin{array}{l}\text { Contributions/benefits (ln) } \\
\text { 2001-2003 }\end{array}$ & $\begin{array}{c}\text { Contributions/benefits (In) } \\
\text { 2004-2006 }\end{array}$ \\
\hline Constant & $\begin{array}{l}1.009 \\
(0.126) * *\end{array}$ & $\begin{array}{l}1.110 \\
(0.144)^{* *}\end{array}$ \\
\hline Benefits (share) ${ }^{1}$ & $\begin{array}{l}-0.032 \\
(0.010) * *\end{array}$ & $\begin{array}{l}-0.053 \\
(0.016) * *\end{array}$ \\
\hline Accession states & & $\begin{array}{r}-0.289 \\
(0.164)\end{array}$ \\
\hline Observations & 15 & 25 \\
\hline$R$-squared & 0.33 & 0.23 \\
\hline
\end{tabular}

Notes: Table uses ordinary least squares (OLS) regression. Robust standard errors in parentheses. $*$ significant at $5 \%$;* significant at $1 \%$.

${ }^{1}$ Index of requests made, homicides, and violent deaths.

spectrum of global and regional security governance challenges. It is reasonable to expect that a deepening and broadening of EU prerogatives in security governance will only occur if the member states perceive the costs and benefits of collective security provision as fair. We have argued that the risk of uneven burdens or free-riding varies according to policy area. Where there is a high risk of freeriding, EU members face a choice. They can either accept most of the burden to 
be shouldered by a few members who could then dictate the direction of policy "on the ground"; for example, the decisive French contribution to European Union Force (EUFOR) in the Democratic Republic of Congo provided Paris with leverage over the mission's implementation. Alternatively, the larger states can institutionalize security cooperation in such a way as to minimize small-member freeriding (for example, place the ESDP or JHA under the Community method).

Generalizing insights from public-goods models, joint-product models emphasize the importance of specifying issue-specific aggregation technology and asymmetric costs and benefits. Here, we have introduced a new categorization of security governance, but notably careful empirical testing fails to yield evidence that consistently supports the theoretical expectations derived from these models for EU security governance. For assurance and protection, we observe instead that smaller countries carry a heavier load. Admittedly, in both areas, the absolute burden borne for the common policies remains modest. Possibly, the EU members "trade in public goods"; ${ }^{26}$ the smaller EU members specialize in internal and external policing tasks, assurance and protection, and leave military coercion, compellence, to the larger EU members. Nonetheless, we are still left with an unexpected finding, namely that burdens are shared evenly in compellence and prevention.

Since we cannot aggregrate the indicators for the four policy areas into a single index of effort, it is difficult to evaluate the net balance of the contributions of large and small countries. It is, however, possible to aggregate personnel committed to assurance and compellence missions. The rank-order correlations between personnel contribution (relative to population) and capacity to pay (measured as size and wealth) show that we generally cannot reject the null hypothesis of even burden-sharing. ${ }^{27}$ Any evidence suggesting that larger or richer countries contribute disproportionately dissipates when the EU15 and accession states are analyzed separately, a meaningful differentiation given the incomplete and ongoing socialization of the latter as EU member states. Nor is there a significant relation between the rank-ordering of contributions to the various areas of security policies. The Kendall tau-statistics show a significant positive correlation between contributions to assurance and protection policy areas (to which smaller countries contribute more) on the one hand, and prevention and compellence policies (to which wealthier countries contribute more) on the other.

As our analysis of security governance demonstrated, it is important to carefully identify the factors that may uniquely determine burden-sharing in particular policy areas. It seems reasonable to expect that the same would apply to other policies, such as immigration and asylum, weapons procurement, or epidemiolog-

26. Boyer 1989. Relatedly, Thielemann and Dewan 2006 propose a division of labor between the proactive (larger) and reactive (smaller) EU members with respect to refugee protection.

27. Aggregating contributions to assurance and compellence, the Kendall tau- $b$ with size and wealth equaled $.453(\mathrm{p}=.002)$ and $.360(\mathrm{p}=.013)$ respectively. Excluding contributions to NATO missions, the Kendall tau- $b$ with size equals $.147(\mathrm{p}=.315)$ and with wealth $.347(\mathrm{p}=.016)$. However, none of these rank-correlations remained significant when analyzing EU15 and accession states separately. 
ical surveillance. A further contribution of our research has been to focus on burdensharing within the EU rather than on the NATO or UN. ${ }^{28}$ Arguably, joint-product models should apply generally, and it would be interesting to explore their relevance for the provision of regional security more generally. At the same time, we are aware of the highly institutionalized and sui generis nature of the EU as an international organization. The issue of burden-sharing is rendered generally moot for policies falling under Pillar I (for example, prevention) that are financed from Community budget. Only EDF contributions remain subject to an unfettered national prerogative. Here we observe that richer countries and those that generally spend more on foreign aid contribute disproportionately to the EDF. Compellence conforms to the expectations of the joint-product models: lower marginal costs of providing troops best explain uneven contributions - a factor clearly shown by the unique importance of NATO membership to explain contributions to NATO/U.S.led military operations.

The absence of chronic free-riding in the four categories of EU security governance policy confounds the expectations of public-goods models. The high degree of national policy integration and institutionalization within the EU may explain why free-riding does not pose a serious problem to the provision of collective security goods, but it is less clear why we observe the smaller states making disproportionately large contributions to the policies of assurance and protection. This perhaps unexpected small-state behavior even holds when allowing for any unequal distribution of benefits; in other words, contrary to Chalmers, we cannot find any "small-state bias," at least regarding common EU security policies. ${ }^{29}$ The most likely explanation is that assurance and protection so far only require minor, possibly even symbolic, contributions; for example, a total of 1,722 person years are deployed to civil crisis management compared to 232,111 to military missions. Arguably, the smaller EU member states' willingness to make disproportionately large, albeit in absolute terms small, contributions reflects a political calculation that those contributions will supply the necessary credibility for shaping the future development of common security policies.

The equitable burden-sharing in each category of security governance also demonstrates that the different aggregation technologies that apply to the four security areas-summation for assurance and prevention, best-shot for compellence (and somewhat less clearly prevention), and weakest-link for protection-do not pose insurmountable barriers to the optimal supply of public goods. The high degree of

28. With the exception of NATO-led military operations, we exclude national policies undertaken outside the EU framework from our analysis. Our primary concern is the contribution of EU member states to the EU as a security actor. NATO-led missions are included owing to the tangled and overlapping memberships in NATO and the EU. Moreover, the Berlin plus agreements explicitly acknowledge that NATO will provide force projection capabilities and serve as the forum for coordinated action where the interests of EU member states and the other members of NATO overlap. Thus, contributions to NATO and contributions to EU missions cannot be meaningfully disentangled although they are legally separable. We have chosen to focus on the de facto rather than de jure status of combat missions.

29. Chalmers 2000. 
policy coordination and integration in all three pillars of the EU, and the norms conditioning reflexive compliance with Commission rules, suggest that either lower marginal costs (as in the case of compellence) or higher political benefits (as in the case of assurance for the accession states) better explain the disproportional contributions of EU member states to security governance. Thus, the institutional and normative frameworks governing EU member-state security policies blunt the anticipated political pathologies ascribed to the different technologies of publicgoods production.

\section{References}

Arce M., Daniel G., and Todd Sandler. 2002. Regional Public Goods: Typologies, Provision, Financing, and Development Assistance. Stockholm, Sweden: Almkvist and Wiksell.

Boyer, Mark A. 1989. Trading Public Goods in the Western Alliance System. Journal of Conflict Resolution 33 (4):700-29.

Buchanan, James. 1965. An Economic Theory of Clubs. Economica 32 (125):1-14.

Chalmers, Malcolm. 2000. Sharing Security. The Political Economy of Burdensharing. Houndmills, U.K.: Macmillan.

Hill, Chris. 1993. The Capability-Expectation Gap, or Conceptualising Europe's International Role. Journal of Common Market Studies 31 (3):305-28.

Hirshleifer, Jack. 1983. From Weakest-Link to Best Shot: The Voluntary Provision of Public Goods. Public Choice 41 (3):371-86.

Hix, Simon. 1999. The Political System of the European Union. Houndmills, England: Palgrave.

Jones, Seth G. 2007. The Rise of European Security Cooperation. Cambridge: Cambridge University Press.

Khanna, Jyoti, and Todd Sandler. 1996. NATO Burden Sharing: 1960-1992. Defence and Peace Economics 7 (2):115-33.

1997. Conscription, Peace-keeping, and Foreign Assistance: NATO Burden Sharing in the Post-Cold War Era. Defence and Peace Economics 8 (1):101-21.

Kirchner, Emil J., and James Sperling. 2007. EU Security Governance. Manchester, England: Manchester University Press.

Koenig-Archibugi, Mathias. 2004. Explaining Government Preferences for Institutional Change in EU Foreign and Security Policy. International Organization 58 (1):137-74.

Lindstrom, Gustav. 2005. EU-US Burdensharing: Who Does What? Chaillot Paper 82. Paris: Institute for Security Studies.

Noël, Alain, and Jean-Philippe Thérien. 1995. From Domestic to International Justice: The Welfare State and Foreign Aid. International Organization 49 (3):523-53.

Olson, Mancur. 1965. The Logic of Collective Action: Public Goods and the Theory of Groups. Cambridge, Mass.: Harvard University Press.

Olson, Mancur, and Richard Zeckhauser. 1966. An Economic Theory of Alliances. Review of Economics and Statistics 48 (3):266-79.

Sandler, Todd. 1977. Impurity of Defense: An Application to the Economics of Alliances. Kyklos 30 (3):443-60.

1992. Collective Action: Theory and Applications. Ann Arbor: University of Michigan Press.

Sandler, Todd, and John F. Forbes. 1980. Burden Sharing, Strategy, and the Design of NATO. Economic Inquiry 18 (3):425-44.

Sandler, Todd, and Keith Hartley. 2001. Economics of Alliances: The Lessons for Collective Action. Journal of Economic Literature 39 (3):869-96. 
Sandler, Todd, and James C. Murdoch. 2000. On Sharing NATO Defence Burdens in the 1990s and Beyond. Fiscal Studies 21 (3):297-327.

Sandler, Todd, and John Tschirhart. 1980. The Economic Theory of Clubs: An Evaluative Survey. Journal of Economic Literature 18 (4):1481-521.

Shizumu, Hirofumi, and Todd Sandler. 2002. Peacekeeping and Burden-Sharing, 1994-2000. Journal of Peace Research 39 (6):651-68.

Smith, Michael E. 2004. Europe's Foreign and Security Policy: The Institutionalisation of Cooperation. Cambridge: Cambridge University Press.

Sperling, James, and Emil J. Kirchner. 1997. Recasting the European Order: Security Architectures and Economic Cooperation. Manchester, England: Manchester University Press.

Thielemann, Eiko R., and Torun Dewan. 2006. The Myth of Free-Riding: Refugee Protection and Implicit Burden-Sharing. West European Politics 29 (2):351-69.

Webber, Mark, Stuart Croft, Jolyon Howorth, Terry Terriff, and Elke Krahmann. 2004. The Governance of European Security. Review of International Studies 30 (1):3-26. 